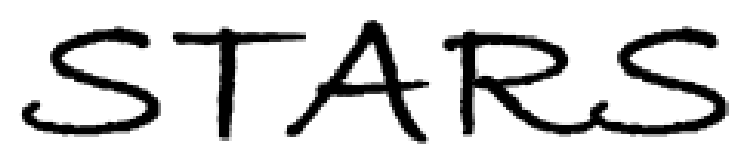

University of Central Florida

STARS

Faculty Scholarship and Creative Works

4-1-1974

\title{
Mordechai Gumpel Schnaber: The First Religious Reform Theoretician of the Hebrew Haskalah in Germany
}

M Pelli

Find similar works at: https://stars.library.ucf.edu/ucfscholar University of Central Florida Libraries http://library.ucf.edu

This Paper is brought to you for free and open access by STARS. It has been accepted for inclusion in Faculty Scholarship and Creative Works by an authorized administrator of STARS. For more information, please contact STARS@ucf.edu.

\section{STARS Citation}

Pelli, M, "Mordechai Gumpel Schnaber: The First Religious Reform Theoretician of the Hebrew Haskalah in Germany" (1974). Faculty Scholarship and Creative Works. 65.

https://stars.library.ucf.edu/ucfscholar/65

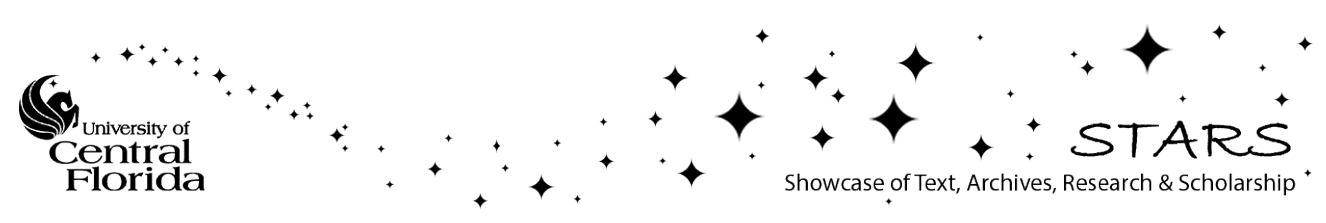


Mordechai Gumpel Schnaber: The First Religious Reform Theoretician of the Hebrew Haskalah in Germany Author(s): Moshe Pelli

Source: The Jewish Quarterly Review, New Series, Vol. 64, No. 4 (Apr., 1974), pp. 289-313 Published by: University of Pennsylvania Press

Stable URL: http://www.jstor.org/stable/1453984

Accessed: 16-03-2017 13:07 UTC

JSTOR is a not-for-profit service that helps scholars, researchers, and students discover, use, and build upon a wide range of content in a trusted digital archive. We use information technology and tools to increase productivity and facilitate new forms of scholarship. For more information about JSTOR, please contact support@jstor.org.

Your use of the JSTOR archive indicates your acceptance of the Terms \& Conditions of Use, available at http://about.jstor.org/terms

University of Pennsylvania Press is collaborating with JSTOR to digitize, preserve and extend access to The Jewish Quarterly Review 


\title{
MORDECHAI GUMPEL SCHNABER: THE FIRST RELIGIOUS REFORM THEORETICIAN OF THE HEBREW HASKALAH IN GERMANY
}

\author{
By Moshe Pelli, Ben-Gurion University of the \\ Negev, Beer-Sheva, Israel
}

LIKE MANY of his fellow-maskilim, Mordechai Gumpel Schnaber, known also as George Levison, has been a controversial figure during his lifetime, and an enigma to this day. Perhaps it is owing to his stature as a well known physician and as one of the first Jews to have been given the title of Professor, that a number of articles have been devoted to him in recent years. Although this is more than could be said about many other maskilim of the early period of Haskalah in Germany, these articles either lay the groundwork of sketching his life or else treat aspects of his writings which are only secondary to Schnaber's role in the Hebrew Haskalah. ${ }^{1}$ It is for this reason that the current endeavor is

1 Following are the most important references dealing with Schnaber (in alphabetical order):

Edward Duckesz, Chachme AHW [The Sages of AHW] (Hamburg, I908), pp. 32, 93 [in the German and Hebrew sections, respectively]; Samuel Fünn, "Safah Lene’emanim," ["Language for the Trustworthy”] Hakarmel, IV (July, I879) pp. 396-397; Julius Fürst, Bibliotheca Judaica, II (Leipzig, I85I), pp. 238-239; Heinz Mosche Graupe, "Mordechai Gumpel (Levison)," Bulletin des Leo Baeck Instituts, V(No. I7, June, I962), pp. I-I2. Graupe's article is by far the most exhaustive, up-to-date study of Schnaber; it presents first a short biography of Schnaber which is based on some new data published by Schoeps (see below), thus correcting previous information on the Hebrew physician. The article further discusses Schnaber's philosophy which is said to be antithetical to that of the Hebrew and German Haskalah. The Jewish Encyclopedia, VIII (I9r6), p. 46; Ben-Zion Katz, "Toldoth Haskalath Hayehudim Berusiah," ["The History of the Enlightenment of the Jews in Russia"] Hazman, I(January-April, I903), pp. 80-8I; G. Kressel, Lexicon Hasifruth Hacivrith Badoroth Ha'aharonim [Cyclopedia of Modern Hebrew Litevatuve], II(Merhaviah, 1967), p. 954; F. Laḥover, Hasifruth Hacivrith Hahadashah [Modern 
undertaken, namely, to examine the Hebrew works of the said maskil from the angle of Hebrew Haskalah of which indeed he has been a part. ${ }^{2}$

In his advocacy of Enlightenment, Schnaber preceded the Hebrew German maskilim both in preaching and in practice

Hebrew Literature], I (Tel Aviv, I928), p. 9I ; Raphael Mahler, Divvei Yemei Yisra'el[:] Doroth 'A havonim [History of the Jewish People in Modern Times], I, 2(Merhaviah, I954), pp. 54, 8I ; Moses Margoliouth, The History of the Jews in Great Britain, II(London, I85I), pp. I I8-I I9; Josef Meisl, Haskalah (Berlin, I919), p. I6; James Picciotto, Sketches of Anglo-Jewish History (London, I875), p. I44; Cecil Roth, "The Haskalah in England," Essays Presented to [.. . I Israel Brodie (London, I967), pp. 367-368; Hans Joachim Schoeps, "Gumpertz LevisonLeben und Werk Eines Gelehrten Abenteurers des I8. Jahrhunderts," Zeitschrift für Religions- und Geistesgeschichte IV(1952), pp. r50-I6r, republished also in his book Studien zur unbekannten Religions- und Geistesgeschichte (Berlin, 1963), ss. 216-227; Translated into French: "La Vie et l'Euvre de Gumpertz Levison," Revue d'Histoive de la Médicine Hébraïque, XXVII(I955), pp. I33-I43. It is a short, up-todate biography debunking several long-held details of Schnaber's life. See also Schoeps, Barocke Juden Christen Judenchristen (Bern, I965), ss. I09-II3, and his article "Läkaren och Alkemisten Gumpertz Levison," Lychnos (Uppsala, r944), 230-248. Siegfried Stein, "Sefer Giddul Banim," Remember the Days. Essays in Honour of Cecil Roth (Oxford, I966), pp. I68-169; Israel Zinberg. Toldoth Sifruth Yisva'el [History of the Literature of Isvael], V (Merhaviah \& Tel Aviv, I959), p. 290.

2 As I shall discuss it below, I disagree with Graupe's view in his article (cited above) that Schnaber did not belong to the circle of the Hebrew maskilim. The Hebrew maskil started his Haskalah activities long before the formation of the circle of the maskilim:dissemination of scientific knowledge in the Hebrew language (in his book מאר [AnEssay (of) the Torah and Wisdom], (London, r77I) heralded a similar trend of the Hebrew Haskalah. Schnaber stressed, already at this early stage of Hebrew Haskalah, the necessity for the revival of the Hebrew language. In $\mathrm{I} 784$ Schnaber published excerpts from his book on that subject in Hame'assef, encouraging the editors to proceed with their struggle for Enlightenment, although not through extreme and war-like ways. A detailed description could be found in my study entitled The Attitude of the First Maskilim toward the Hebrew Language (Austin, Texas, I970; Beer Sheva, Israel, I972), scheduled for publication in 1974 in the Bulletin of the Institute of Jewish Studies (London). His other works, too, typify the ways of the Hebrew Haskalah: A modern interpretation of Maimonides, and an exegesis of the book of Koheleth. A detailed discussion will follow. 
by some twelve or thirteen years; in his allusion, at first, and direct reference later to religious reform, he preceded the more extremist German Jewish reformers by some two decades. Thus, Schnaber could be considered as one of the early enlighteners of the Hebrew Haskalah, ${ }^{\mathbf{3}}$ and perhaps as the first maskil who alluded to religious reforms at the time. Significantly, the tools used by Schnaber for his Enlightenment and religious reform purposes are taken mostly from the old, traditional school, namely, exegesis of revered texts and a philosophical and theological interpretation of Maimonides.

This use of the traditional form and style may explain the presence of traditional views alongside with Schnaber's more advanced ideas. His conservatism is in no way unique to him; for, in effect, we have found a similar trend in the writings of some of the other Hebrew maskilim. ${ }^{4}$ Undoubtedly,

3 Schnaber's utterances on the Hebrew language in $M a^{\text {'amar }}$ Hatorah Vehahochmah, p. 5, are regarded by Cecil Roth as "almost a Haskalah manifesto!" ("The Haskalah in England," p. 368). Roth suggests that Schnaber might have been the author of another early Haskalah work, Sefer Giddul Banim, containing suggestions of educational reforms (ibid., p. 367). Siegfried Stein, in his article on "Sefer Giddul Banim," pp. I68-I69, rejects Roth's suggestion.

4 See my book משה מנדלסון: בכבלי מסורת [Moses Mendelssohn; Bonds of Tradition] (Tel Aviv, 1972), and my articles: "Intimations of Religious Reform in the German Hebrew Haskalah Literature," Jewish Social Studies, XXXII (No. I, January, I97o), pp. 3-I3; "The Methodology Employed by the Hebrew Reformers in the First Reform Temple Controversy (1818-1819)," Studies in Jewish Bibliography, History and Literature in honor of I. Edward Kiev(New York, I97I), pp. 38I-397; “The Religious Reforms of 'Traditionalist' Rabbi Saul Berlin (A Chapter in the History of the Struggle of Hebrew Haskalah in Germany for the Revival of Judaism)," Hebvew Union College Annual, XLII(197I), pp. I-23 [Hebrew]; "Some Notes on the Nature of Saul Berlin's Writings," The Journal of Hebraic Studies, I(No. 2, r970), pp. 47-6I; Naphtali Herz Wessely's Attitude toward the Jewish Religion as a Mirror of a Generation in Transition (During the Early Period of Hebrew Haskalah in Germany) (Beer-Sheva, Israel, I97I), to be published also in Zeitschrift für Religions- und Geistesgeschichte in 1974; Isaac Satanow's 'Mishlei Asaf' As Reflecting the Ideology of the German Hebrew Haskalah (Beer-Sheva, I972), published in Zeitschrift für Religions- und Geistesgeschichte, XXV (No. 3, I973), pp. 225-242. 
Schnaber resembles his contemporary maskilim in this regard for he, too, typifies his generation as a generation of transition. While all generations are in transition, the one under study may be more representative of an overall transition, from one historic period to another, which lasted for a century, till the end of the Haskalah in the last quarter of the Igth century.

The use of the writings of Maimonides as a springboard for Enlightenment is also quite typical of the maskilim in their search for a guide, an authoritative guide, to enhance their ideas and ideals. ${ }^{5}$

The explanation cited above regarding the presence of the elements of the new and the old together in Schnaber's Hebrew writings is not fully understood, or at least not expressed, by most students of the period, of its thought and literature.

One suspects that the complexities of the Hebrew Haskalah and its exponents are being ignored at times, for the sake of simplification and generalization. The purpose, it seems, is to make the Hebrew Haskalah more homogeneous, and thus more understandable, than it actually was.

Although these comments do not fully fit the very fine study of Schnaber by Graupe, some generalities in that study are believed to be erroneous. At first sight, writes Graupe,

5 Solomon Maimon writes about his great admiration and indebtness to Maimonides in his autobiography, The Life of Solomon Maimon (Tel Aviv, 1953), pp. 260-26r [Hebrew]. Solomon Maimon as well as other maskilim published commentaries on Maimonides' works: Moveh Nevuchim [Guide for the Perplexed] (Berlin, I79I); Mendelssohn's commentary on Miloth Hahigayon [Words of Meditation, or Logic], first published in I76r. Quotations from Maimonides in the writings of the maskilim and their application to the furtherance of Haskalah goals are too numerous to cite. Cf. F. Lahover, "Harambam Vehahaskalah Hacivrith Bereshitah" ["Maimonides and the Early Hebrew Haskalah'], Moznayim, III (I-6, Tishrei-Adar Bet, I938-39), pp. 539546; Joseph Schechter, "The Attitude of the Haskalah Generation and Our Generation to Maimonides," Limudei Hayahaduth Bahinuch Hacal Yesodi [Judaic Studies in Post Elementary Education (Tel Aviv, I968), pp. 107-I ro [Hebrew]; Isaac Eisenstein-Barzilay, "The Ideology of the Berlin Haskalah," Proceedings of the American Academy for Jewish Research, XXV(1956), pp. 4-7. 
Schnaber would appear, after having read a short biography of him, as an assimilationist, as an outspoken defender of Enlightenment, as though he stood close to the circle of the Me'assfim, the Hebrew enlighteners. A completely different picture emerges from his Hebrew writings, writes Graupe; accordingly, he was not in the circle of the enlighteners, in the circle of Mendelssohn, Herz, Euchel and Friedländer. ${ }^{6}$ Associating "assimilationist" with "an outspoken defender of Enlightenment," even in his context, is rather strange. For it may mislead the reader to believe that the writer is dealing with synonymous terms, namely, that "assimilationist" and "enlightener" are necessarily identical. Further, it appears that Graupe does not believe that Schnaber has anything to do with the Hebrew maskilim, their movement, their writings, and their ideology. Although Schnaber may not have adhered to the same philosophical principles of the Wolffian school which were held by Mendelssohn, the two still have many other ideas in common in the spheres of Judaism, theology, and Hebrew Haskalah. The ambivalent attitude toward tradition on the one hand, and toward enlightenment on the other, is typical of both maskilim. ${ }^{7}$ There is the attempt on the side of both maskilim to preserve Judaism and to defend it in the face of extreme anti-Jewish views among the European enlighteners. Yet they also endeavored to introduce Enlightenment into Judaism. Putting Mendelssohn and Friedländer together is not as simple as it may appear, as indeed any one familiar with the subject at hand surely knows. In addition, the circle of Hame'assfim was not a unified body with unified Weltanschauung; the editors of Hame'assef changed, and more often its writers did.

Schnaber's views, as discussed below, indeed show his part in the Hebrew Haskalah. In spite of my disagreement with some of Graupe's views on Schnaber, I think that his conclusions are quite meritorious; Schnaber should be considered

${ }^{6}$ Graupe, "Mordechai Gumpel (Levison)," pp. 5-8.

${ }^{7}$ Cf. Moshe Mendelssohn: Bechavlei Masoreth, pp. 9, I8-19, 75-84. 
as a definite representative of Enlightenment, but only of one segment of Haskalah.

My discussion below attempts to prove that.

Schnaber's first book, מאמר התורה והחכמה, was published in I77I in London, where he stayed for his medical education and practice. The book is an encyclopedia of knowledge dealing with mathematics, physics, and some other sciences, while leaving metaphysics for the second volume that has never been published. ${ }^{8}$ In addition, a long introductory essay in defense of the study of the sciences, shows, or endeavors to show, that Judaism has no objection to the study of these sciences. The essay further analyzes some aspects of traditional Judaism and its books from an Enlightenment point of view.

This kind of apologetical introduction which essentially wishes to show the compatibility of Judaism and wisdom could be found in the writings of the other maskilim in a way that it may reflect both a state of mind of the given writer, as well as the state of mind of his cultural and religious milieu. Occasionally, one is hesitant as to whether or not the attempt to show the compatibility of Judaism and wisdom, that is, the sciences, actually reflects the philosophy of a given writer at the time of writing; perhaps it reflects his awareness of and his reaction to the traditional views of his contemporaries, and thus his writings may assume a compromising tone for strategical reasons.

Unlike a writer such as Isaac Satanow, in whose writings one can detect a shift from the stand that at first shows the rapport between Judaism and secular knowledge, and subsequently reflects a stand that alludes to the dependence of

8 Roth, in his above-mentioned article, believes that the second part of the book remained unpublished because of the controversy regarding Schnaber's character which had been diverted to his book ("The Haskalah in England," p. 368). As I shall point out below, Schnaber's book has not been referred to whatsoever in the controversial writings. Kressel, in his Lexicon, II. p. 954, is of the opinion that Schnaber's third book is taking the place of the second volume of Ma'amar Hatorah. 
the former on the latter, ${ }^{9}$ it is my opinion that in the writings of Schnaber the compatibility of both Judaism and secular studies is an integral part of his established Weltanschauung. We do not see a development here from the former attitude toward Judaism to the latter, but indeed the same attitude prevails in all his Hebraic writings. Thus the contents of his books, his style, and his manner of presentation bespeak as follows: Haskalah and secular knowledge are not the contribution of the modern age to Judaism, but rather a re-introduction to Judaism of the sciences-although in a modern, up-to-date fashion-which have been neglected as a result of circumstances.

"There is nothing in wisdom [תכמה, i.e., secular knowledge] which will disobey [= contradict] the Torah", ${ }^{10}$ seems to be the motto of Schnaber as enunciated in the introduction to $M a^{3}$ amar Hatorah Vehahochmah. He illustrates this contention in a graphic way by ending each paragraph of the author's preface with the words תכמה and alternately some ten times, the words being printed in bold type. ${ }^{11}$ The fools say that wisdom objects to [= rejects, contradicts] the fundamentals of Torah, writes Schnaber, whereas the wise ones know that Wisdom and secular knowledge "beautify the Torah and strengthen the foundations of faith." It is for this reason, he writes, ${ }^{12}$ that our ancestors have taught them, i.e., the sciences and secular knowledge. In order to disprove those fools, Schnaber employs various arguments even if they may

9 See my study Isaac Satanow's 'Mishlei Asaf' As Reflecting the Ideology of the German Hebrew Haskalah, cited in note 4. Another article of mine on Satanow has been completed and should be וייצחק סאטאנוב: המין המאמין במילחמתה של ההשכלה: הצברית בגרמניה (200 שנה לראשית יצירירתו)" (באר־-שבע, 1973) [שיכפול].

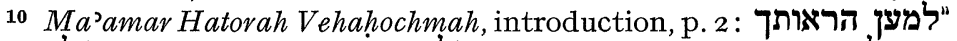

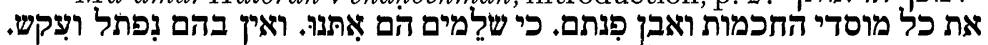
אשר ימרת כת את פי התורה".

11 ibid., p. I, of the introduction.

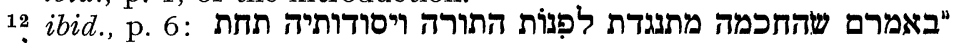

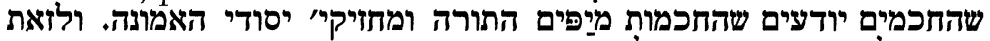

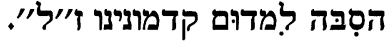


at times sound contradictory. Thus he explains biblical miracles in a scientific way, ${ }^{13}$ claims that secular knowledge does not have any connection whatever with any foundation of our faith, ${ }^{\mathbf{1 4}}$ yet maintains elsewhere in the book that without the knowledge of certain secular disciplines one may not be able to observe a given religious law. ${ }^{15}$

In a like manner, Schnaber endeavors to present his case with regard to talmudic Judaism. The various parts of the Talmud are full of חכמות, i.e., secular knowledge, and the rabbis have never ordered to discard the study of such disciplines. ${ }^{16}$ Schnaber further elucidates the place of חכמה, that is wisdom, common sense, reason, and/or logic, in the Talmud. "All their utterances are based on the principles, or foundations, of reason and agree with true search $[=$ philosophical examination]", maintains this maskil. ${ }^{17}$ There is nothing innovative or original about these beliefs, for they are in effect paraphrases taken from medieval Jewish philosophy. However, they do indeed express the viewpoint of the Hebrew Haskalah of the time in contrast with the contemporary views and practices as represented by most of the traditional rabbis. Following the line of Haskalah, Schnaber points out

13 "שמש בגבצון דום" is explained rationally by Schnaber (ibid., p. I9). The sun being in the center of the universe is explained as being behind the Psalms, I9:5 verse: לשֶמש שטם אוהל בהם ["In them hath he set a tabernacle for the sun'] (ibid., p. I8). Similarly, the talmudic scholars may have hinted at the possibility of other habitable planets when they said: צתיד הקב"ה להנחיל לכל צדיק שי"י צולמות ["The Holy One blessed be He will bestow on each righteous man three hundred and ten worlds"'] (Ibid., p. r9; A version of this talmudic saying appears in Sanhedrin, Iooa).

\section{"רוב תלקי החכמות [... אין אין להם שייכות כלל ליסוד אחד מאמונתינו. 14}

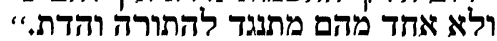

["Most disciplines [. . . ] have no connection at all with any fundamental of our faith; not a single one of them contradicts either the Torah or the religion'] ( $M a^{2}$ amar Hatorah, p. 9).

15 Without the knowledge of chronology and geography we would not know the exact timing of Shabath and the holidays (ibid., p. 24).

16 ibid., p. 8: “"

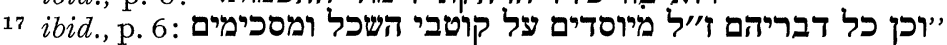

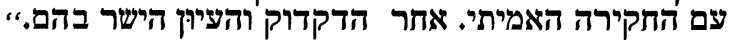


that the cause for the state of Judaism in his time is גלות. As a result, Torah and the teaching of Torah are now in the hands of unwise people, he writes, who do not equip the youths with the proper understanding of the Talmud, or for that matter of Judaism. This kind of teaching creates confusion in the mind of the youths; to confront this confusion the rabbis forbid the learning of philosophy and of secular studies. ${ }^{18}$ Schnaber rejects this attitude on the part of the rabbis as well as the old-fashion teaching of the Talmud; instead, he suggests that the Talmud should be taught without the casuistry, in accordance with the פשט, the straight-forward, common-sense understanding of a text. ${ }^{19}$ It is a very unwise policy to persecute those who seek חכמה, for it causes the lessening of Torah, according to this maskil. The study of the sciences and secular knowledge is left to "strangers," (זרים), in his words, who do not comprehend the acts of God, thus they are unable to bridge between the sciences and Judaism. ${ }^{20}$ Denial of logical examination is compared by Schnaber to the expulsion form עדן ${ }^{21}$ One such use of

18 ibid., p. 8: :

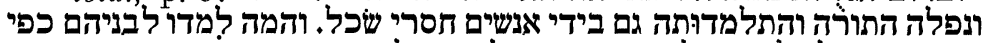
דרכם הכסל ולקחו כל הענינים שבתלמוד על ביר דרך אחד;")

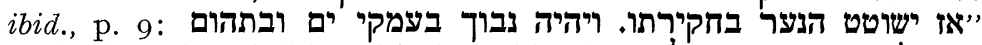

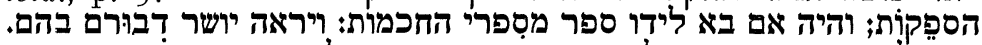

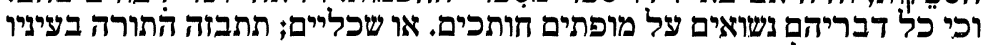

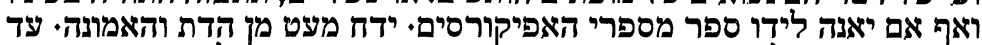

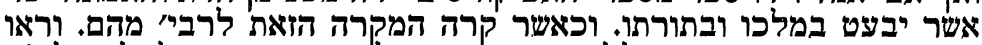

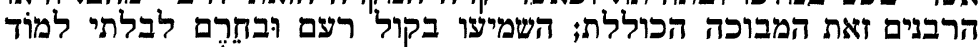

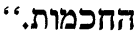

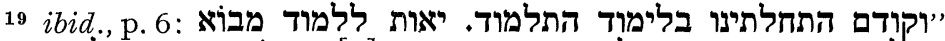

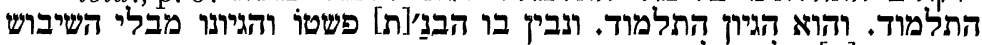

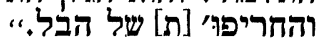

$C f$. Naphtali Herz Wessely's views on the proper study of the Talmud in מברי שלום ואמת [Words of Peace and Truth], I (Berlin, I782), p. I6b

my pagination].

20 Ma'amar Hatorah Vehahochmah, in the introduction:

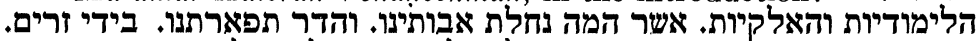

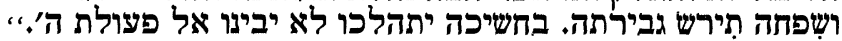

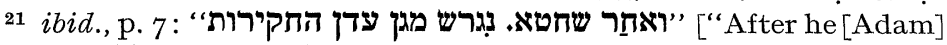
had sinned he was expelled from the garden of Eden of examination."'] 
the logical examination is applied by the writer to טעמי המצוווֹת, the reasons for the precepts. Going in the footsteps of medieval Jewish philosophers, and heralding a similar trend in the Hebrew Haskalah, Schnaber feels the necessity of giving a rational explanation to the mitzvoth. ${ }^{22}$

These views by Schnaber so far are indicative of his Enlightenment tendencies; however, they do not represent by themselves any direct trend toward reforms or changes in the Halachah. An important step in the direction of religious reform could be found, however, in this early work of Schnaber. In his discussion of the reasons why תורה שבעל פה, the Oral Law, had not been given in writing, Schnaber cites Maimonides' explanation which is based on the Talmud: Things given orally may not be transcribed in writing, for the limitation of language is bound to cause confusion and conflicting תורה understanding of the text. It is for this reason that שבכתב, the Written Law, had been given in writing, for it is the essence of Judaism; however, its interpretation had been given orally through tradition to allow בית דין הגדול [Supreme Court, or Sanhedrin] to decide which is the right tradition and which is the right interpretation of the Torah. ${ }^{23}$

Schnaber neither accepts nor rejects this explanation by Maimonides; instead, he suggests another explanation whose original author is also that medieval Jewish philosopher, and which is taken out of context and applied here. ${ }^{24}$ Accordingly,

22 Following especially Maimonides whom he cites; see ibid., pp. 7-8. Some of the explanations: to rid the Israelites of pagan and false beliefs, to instill in them the true beliefs, and to strengthen love and brotherhood of mankind.

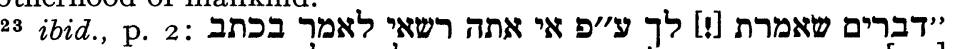

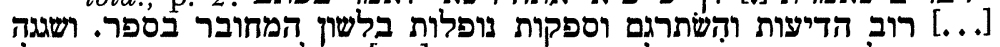

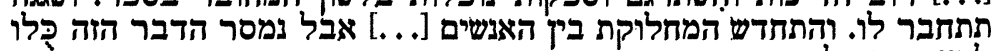

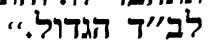

24 Maimonides, מורה נבוכים [Guide for the Perplexed], III(Berlin, I795), p. 5Ia, Satanow's edition, deals with the question of the authority of the judges; the authority to enact certain changes is said to have been given to the Bet Din Hagadol alone so as to avoid confusion and various and possibly conflicting interpretations of the law. 
it is not the language which may cause misunderstanding and misinterpretation, but the laws of the Torah which will need some changes in the face of the changing times and the changing places. To prevent the necessary changes, the Torah itself has forbidden any additions or subtractions, for these would cast some doubt as to the origin and authenticity of the Torah and its laws. Yet in order to provide the legal mechanism for the maintenance of the original laws, the Supreme Religious Court, or the rabbis of each generation, are given the authority to add סייגים, i.e., preventive and protective fences around the essence. ${ }^{25}$ Now Schnaber adds his own contribution to the subject: "And if the Oral Law were in writing, the rabbis would not have been able to make any innovation, and also the masses would not have accepted their decrees except what is written; for this reason the rabbis were given the interpretation of the מצוות and the branching of the דינים that is the legal interpretation of the Written Law-was intended to be oral for the declared purpose of providing the

25 ibid.; Ma'amar Hatorah Vehahochmah, p. 2: "אבל הותר לחכמרים

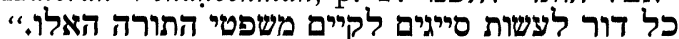

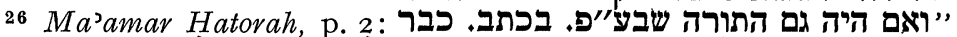

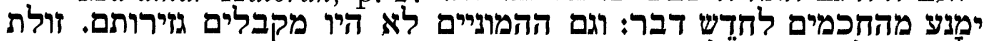

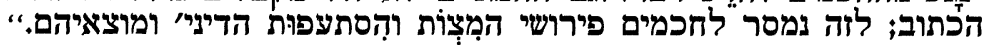
Apparently these heavily loaded words did make their impression some three decades later; for we find in the writings of the Hebrew reformer Rabbi Aharon Horin an almost identical wording, as follows:

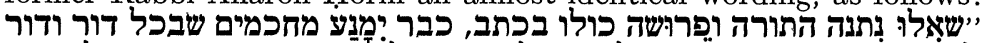

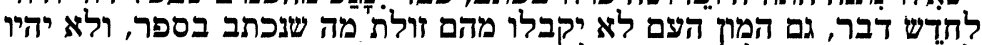

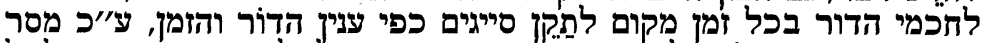

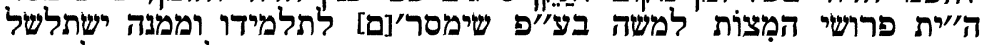

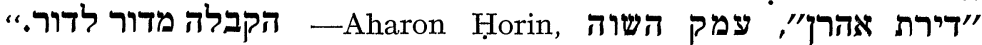
["Aharon's Lodging," The Valley of Shaveh] (Prague, I803), p. 65b. Israel Zinberg has already pointed out some other similarities between Horin and Schnaber, Toldoth Sifruth Yisva'el, V, pp. 290-29r. See also my study of Horin: "Ideological and Legal Struggle of Aaron Chorin for Religious Reform in Judaism," Hebrew Union College Annual, XXXIX(I968), pp. 63-79 [Hebrew]. The literary echo of these views came a century later in Reuven Asher Broides' novel dealing with the subject of religious reform, הדת והחיים [Religion and Life], II(Lemberg, I876), p. 55 . 
rabbis in each generation with the legal tool for developing the Halachah in accordance with the changing times.

It is important to note that in the context Maimonides is dealing with the necessity of having the courts as the sole interpreters of the law, whereas Schnaber is using the quote from Maimonides to emphasize the necessity of change in the law, and the provision in the law itself for that change. Indeed this maskil is endeavoring to establish one very important enlightenment idea, that of the relativity of the divine law itself and its dependence on its time and its place. ${ }^{27}$ Whereas the deists of the $I 7$ th and I8th centuries have been using this idea as an argument in order to show that this law cannot be absolute, ergo cannot be of a divine origin, ${ }^{28}$ the Hebrew maskil is far from desiring this result. To him, the law is divine; however, it is not absolute so as not to be obsolete. In other words, the divine legislator has made provisions within the law for necessary changes which are unavoidable.

I think it is another example of an Enlightenment idea which has been used by the deists to attack Christianity, utilized in a moderate way by a Hebrew maskil. ${ }^{29}$ It looks as if Schnaber is achieving two goals simultaneously; although he does not say it in a direct way, Schnaber is alluding to the possibility of the continuous existence of the Jewish law, and thus of Judaism, in spite of the changes, indeed because of the changes, unlike perhaps other religions which have not

27 Ma'amar Hatorah Vehahochmah, pp. 2-3. Although Schnaber does not speak directly and specifically of the divine law as such, any discussion of the Written Law as presented by him is a discussion of the divine law; indeed, an interpretation of the Written Law according to the circumstances is in effect a limitation of the divine law itself.

${ }^{28} C f$. my study "The Impact of Deism on the Hebrew Literature of the Enlightenment in Germany," Eighteenth-Century Studies, VI (No. I, Fall, I972), pp. 35-59; Journal of Jewish Studies, XXIV (No. 2, Autumn I973), pp. I27-I 46.

${ }^{29}$ Cf. my book Moshe Mendelssohn: Bechavlei Masoveth, pp. 78-87; "Isaac Satanow's 'Mishlei Asaf' as Reflecting the Ideology of the German Haiskalah," notes 28-38 and related text. 
had this provision for change. Thus Judaism is superior to the other religions in this regard, an argument used also by Moses Mendelssohn. ${ }^{30}$ On the other hand, there is a message to the rabbis and to the religious authorities of Judaism, as follows: In order for Judaism to continue as it has been, changes ought to be introduced.

I think that here lies the importance of Schnaber and his views in relation to his other writings, and in relation to the Hebrew Haskalah in general.

Apparently, some of his contemporaries in London, too, might have thought this book to be of importance-in a negative way. It is known that Schnaber was involved in a controversy, believed by some writers to have resulted from ideas expressed in his book. ${ }^{31}$ Information on that controversy and its causes are not too clear. However, it appears that Schnaber was expelled from the Duke Place synagogue in London; he published a short pamphlet in his defense, entitled

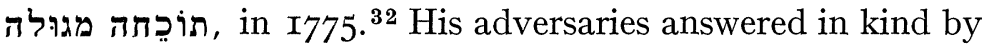
publishing תשוּבת הַפְרוּשישים, accusing Schnaber of adultery,

30 Moshe Mendelssohn: Bechavlei Masoreth, pp. 85-86.

31 Schoeps, "Gumpertz Levison," p. I5I; idem, "La Vie et l'Euvre de Gumpertz Levison," p. I34; Graupe, "Mordechai Gumpel (Levison)," p. 2 ; Roth, “The Haskalah in England,” p. 368. Schoeps writes in his articles that the orthodox Jews of London called Schnaber "Gumpel ha-rascha," citing M. Margoliouth as his source. Checking the source, The History of the Jews in Great Britain, II, p. II8-II9, we find the following information: "The moment his bigoted brethren heard his notions of enlightenment, before they ever read his book, they condemned him, as an infidel and most immoral man, and nicknamed him 'Raa Gumpel,' (Gumpel the wicked.).' There is no way to check Margoliouth's source, for he cites no source; however, no such expression could be found in תשובת הפרושים [The Prushim's Reply] (London, I775 ?), an orthodox attack on Schnaber. Moreover, Schnaber's name is not mentioned at all, but is referred to as "Gershon." Further, the combination "Raa Gumpel" is grammatically wrong. On the other hand, the anonymous writer refers to Gershon's (= Schnaber's) friend and fellow-heretic as "רצע אביש" (ibid., p. 4). "Rac 'avish," is probably a reference to one Rawitch. Is it possible that this is the source of Margoliouth's statement?

32 תוֹסחה מגוּלה [An Overt Reproval] (London, I775 ?); cf. Cecil Roth, Magna Bibliotheca Anglo-Judaica (London, I937), pp. 271-272. 
murder and blasphemy. According to its author, Judah, Schnaber "raised his voice in public [saying] that Torah is not from heaven, and that there is no reward and punishment, denying the resurrection of the dead, eating forbidden food" and not laying תפילין ${ }^{33}$ The writer did not mention Schnaber's book, and thus it is difficult to know what his sources were. It is important to note that Schnaber's defense regarding the expulsion from the synagogue did not contain any reference to his book Ma'amar Hatorah Vehahochmah either; his main concern is to clear himself from the accusation of murder by presenting introductory letters testifying to his innocence and good character. At any rate, his book apparently has not been the center of the controversy. ${ }^{34}$

Schnaber's second. Hebrew work was an exegesis on the book of Ecclesiastes, which came out in Hamburg in I784. In it, this maskil differs with Moses Mendelssohn's interpretation of the biblical book in a number of items which he lists in one of the introductions. ${ }^{35}$ His style and form may represent the old, traditional treatment of a sacred subject; however, the content sometimes exceeds the boundaries of the traditional, and the reader is faced with views unaccepted by the traditional rabbis, views which may indicate Schnaber's reform tendencies. Indeed, it is the synthesis between the old and the new which typifies the writings of this maskil. It is, in my mind, the new which is founded on the old, and draws its support from the latter. קהלת, a book of doubts and skepticism enveloped with somewhat traditional conclusions, provided him with the opportunity to identify with the views expressed by the author of the book, and to present them in a modern, up-to-date, or perhaps relevant way. At times, Schnaber speaks on Koheleth's behalf to the perplexed, guiding him in

33 Teshuvath Haprushim, p. 4.

34 Contrary to the views expressed by the writers cited in note $3 \mathrm{I}$. It stands to reason that had the book been involved in the controversy, Schnaber would have come out in its defense.

35 תilariastes)] (Hamburg, I784), pp. Ia, I4b-16a. 
the true paths of life. ${ }^{36}$ Schnaber portrays himself as a defender of the faith whose goal is to interpret the Torah so as to answer "those who ridicule the words of the Torah, some of whom are even of our people." 37 His defense, however, is not contrary to his enlightenment, indeed it is part of it; we note that he advocates the translation of interpretive works on Judaism into other languages; ${ }^{38}$ although Schnaber does not discuss the translation of the Bible into German, he may havealluded to this controversy of the Hebrew Enlightenment. ${ }^{39}$

He comes out against "the new philosophers," apparently referring to the critics of religion, ${ }^{40}$ and advises the perplexed not to disobey the words of the Torah for there is not yet any proof that the Torah is not true, and there is nothing to contradict its laws. ${ }^{41}$

Not all of the views expressed in the book are that conservative; obviously, many are not. We note Schnaber's attempt to doubt the authenticity of the Masorah, ${ }^{42}$ and to accept unauthorized versions of the Bible which he himself has not even seen. ${ }^{43}$ He further seems to feel that the coming

36 ibid., p. 4ob: נצאמר לכן גם אנחנו להנבוך בדרך התוכחה ושאהלה",

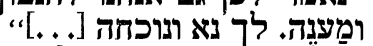

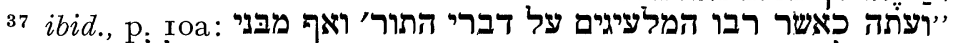

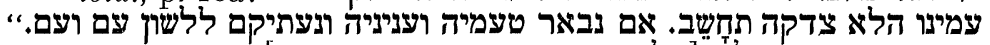

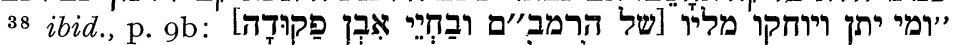
(alluding to Deuteronomy $4: 6)$.

39 ibid., p. Ioa: he actually suggests that an exegesis of the Torah be translated into foreign languages (see note 37).

40 ibid., p. 31a:"הפילוסופים החדשים."

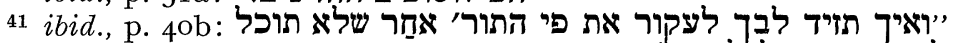

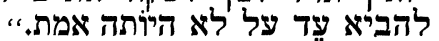

42 ibid., p. rb: The possibility of mistakes in both cantilations and vocalizations is suggested by Schnaber who comes out with the typical

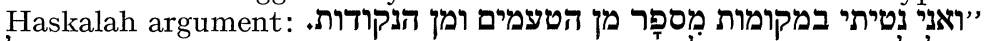

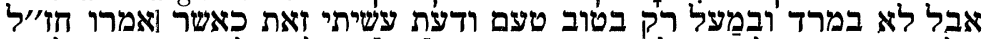

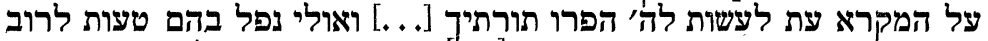

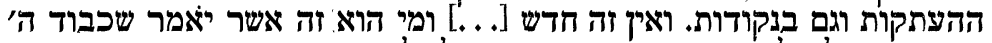
היה שוכן על כל הסופרים ושמר את ידם לבלתי זיח יחטאו."

43 ibid., p. I6a. Schnaber does not accept the last three verses of Koheleth (ch. I2, I2-I4), citing the well-known talmudic source con- 
of the Messiah is not to be regarded as one of the principles of Judaism. Indeed, Schnaber is not original in his view, surely he would not wish to appear as such; he cites Joseph Albo as his authoritative support. The coming of the Messiah, to him, is the coming of everlasting peace, and the belief of all in one creator; it is the time of the cessation of religious hatred. ${ }^{44}$ Clearly, one can note the optimistic hope of the Enlightenment for a new age to come. ${ }^{45}$ Moreover, there is a tendency on the part of the enlighteners to limit the principples of religion to its broader base, that which is common to all positive religions, that which has been the cornerstone of the natural religion. ${ }^{46}$ As we shall later see, Schnaber limits the principles of Judaism to one.

The attitude toward the mitzwoth and their observance on the part of a given maskil is sufficient in most cases to be one of the indicators of his stand with regard to the question of Enlightenment and religion. We note two trends in this book: a. An attempt to preserve the mitzvoth without any change; b. Allusions to the possibility of abolishing the mitzvoth. On the one hand, Schnaber seems to be a maximalist, namely, he would not allow any mitzvah to be overlooked; the abolition of one would necessarily bring about the collapse

cerning the attempt on the part of the sages to eliminate the book from the canon. In addition, he writes that he had been told about an ancient scroll at the king's library in Copenhagen which did not have the controversial three verses. He tried to look for the scroll, could not find it, for someone else had taken it; as he was in a hurry he could not go to that man, thus he has not seen it himself.

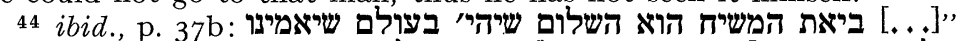

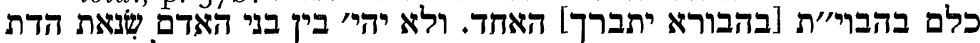

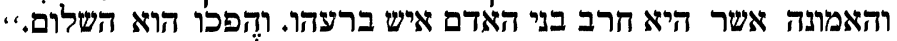

It should be noted that Schnaber is basing this interpretation on Maimonides.

45 Indications of optimistic views are abundant in the Hebrew literature of the period; the new times are depicted as the era of wisdom and knowledge ("נחל הבשוֹר" ["The Brook Besor," or, Good Tidings], Hame'assef, г783, pp. 4, г3; г783-4, p. I I I ; г786, pp. 68, г3 г ; I790, p. 30I).

${ }^{46}$ Cf. Moshe Mendelssohn: Bechavlei Masoreth, pp. 29-3I, 78-87. 
of religion in toto, according to him. ${ }^{47}$ On the other hand, he does toy with the idea that some day the divine legislator would limit the number of mitzvoth; one is reminded of similar, at times identical, enunciations by Mendelssohn. ${ }^{48}$ Schnaber narrows down the purpose of the mitzvoth to two: to instill the love of God and the love of man. It follows that "if people should be able to remember God always, day and night, and to love goodness and reject evil without performing any deeds which should remind them of the fundamentals, perhaps there should not be any [place] for all the mitzvoth." 49 Although it seems possible that the road to religious reform is thus paved by this maskil, it is not at all probable. Somehow like Mendelssohn, who believed that a change in the law may come only through God and through another revelation comparable to the one at Sinai, ${ }^{50}$ Schnaber is not even talking in terms of the immediate future, but of some Messianic times. At that time "there will not be the need for so many mitzvoth," he writes. ${ }^{51}$ The Torah was given originally in order to alleviate a yoke, but not to burden its followers, says the maskil as he elaborates upon a Maimonidian idea. ${ }^{52}$ It is thus up to the lawgiver "to remove it [that is, the Torah] should it be for our good." 53 These views by themselves do not deviate one iota from traditional, talmudic Judaism. There are a number of references in the classical literature regarding the abolition of the mitzvoth "לעתיד לבוא," in the future, meaning: at the

47 Tochahath Megilah, pp. 4oa-b.

48 Moshe Mendelssohn, Yerushalayim (Tel Aviv, I947), p. I37 [Hebrew]; idem, Jerusalem (New York, r969), p. ro4.

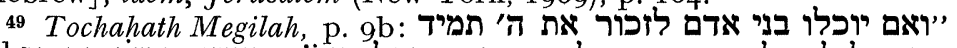

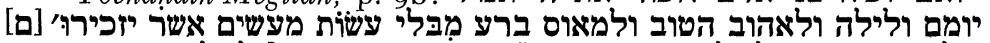

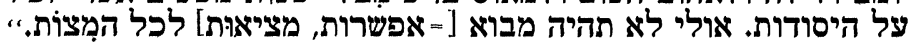
50 See note 48.

51 Tochahath Megilah, p. 9b. Schnaber cites biblical verses which are universally believed to speak of Messianic times, such as the verse

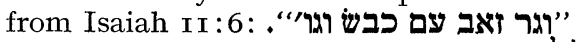

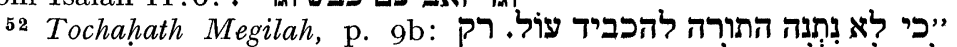

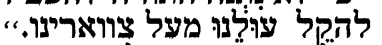

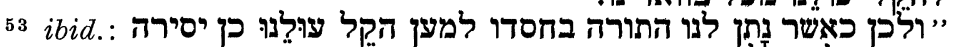


coming of the Messiah. These views by Schnaber, however, do allude to some changes in Judaism which are open to interpretation. Against the background of the Enlightenment thought which envisioned the re-instatement of the original Natural Religion, and against the views of Schnaber regarding the legal mechanism within Judaism which allows for changes, as discussed above, and in anticipation of Schnaber's views in his next book, שלוש עשרה [![י]ודי התורה, I believe it is safe to conclude that we are facing the buds of religious reform.

That year, I784, Schnaber published an article in Hame'assef, organ of Hebrew Haskalah, which started publication a few months earlier. In it the Hebrew maskil welcomes the publication of the Hebrew monthly and mentions his own previous writings in defense of the Hebrew language. ${ }^{54}$ There is no doubt that Schnaber identifies himself with their cause, expresses his wish to assist the Me'assfim-the editors and writers of Hame'assef -in their work of enlightenment, and encourages them against their boorish and zealous adversaries. $^{\mathbf{5 5}}$

In I792 Schnaber published his third work in Hebrew,

54 Hame'assef, I(I784), p. I83. His views were expressed already in $\mathbf{1} 77 \mathrm{I}$ in his Ma'amav Hatorah Vehahochmah, p. 5.

55 Contrary to the views of Graupe that Schnaber was not at all close to the circle of the Me'assfim [Graupe, "Mordechai Gumpel (Levison)," p. 5]. Schnaber welcomed the publication of the journal, encouraging the editors to continue with their enlightenment activities in the face of the attacks by the zealots. According to Ben-Zion Katz, he even solicited funds for their cause (Rabbanuth, Hasiduth, Haskalah [Tel Aviv, I956], p. 25x). He did, however, criticize the editors of Hame assef, very much like Wessely whom he mentioned, although not by name, for publishing satire, and for arousing controversies (Hame'assef, I, I784, p. I 84). The editors apologized, explaining that they had never intended to cause controversy, and that they regarded Schnaber as their strong supporter (ibid.). In the issue that preceded, the editors published a short review of Schnaber's book Tochahath Megilah which contained some very favorable expressions about the author in spite of the fact that in his book he opposes Mendelssohn in his interpretation of the book of Koheleth (ibid., pp. 175-176). 
I6. שלוש עשרה יסודי התורה In addition to the Maimonidian discussion of the thirteen principles, Schnaber has his own interpretation of Maimonides' text with a contemporary, more up-to-date flavor. The nuclear idea of Schnaber is that Judaism is to be narrowed down to one principle, and not to thirteen or three as suggested by Maimonides and Albo, respectively. That one fundamental of Judaism is the belief in the existence of God. All others are secondary to it, stem from it, and do not have the same weight, vitality and significance as the belief in the existence of God.

Very much like the previous book, Yesodei Hatorah has the two tendencies mentioned above: Extreme traditionalism on the one hand, and references to the possibility of religious reform, on the other hand; except that now we have no longer mere allusion to reform, but indeed a direct discussion of it.

There is no doubt in my mind as to the sincerity of Schnaber's traditional tendencies. As a matter of fact, I think that a great portion of the volume is devoted to the defense of Judaism against the current anti-religious writings. Schnaber cites many of the arguments which had been thrown at Judaism by the deists and the atheists, and he refutes them one by one. Such are the claims that Moses had fabricated the Torah by himself, and thus that the stories in the Torah regarding the miracles and the prophecies are false. $\mathrm{He}$ offers historical and scientific evidence to prove the authenticity of biblical stories. ${ }^{57} \mathrm{He}$ further endeavors to

56 Some consider this book to be in lieu of the second volume of his first book, Ma'amar Hatorah, which has never been published. See Kressel, Lexicon Hasifruth Hacivrith, II, p. 954, and $c f$. note 8 above.

57 שלש עשרה [!] יסודי התורה [Thivteen Principles of Torah] (Altona?, I 792), pp. 53a-54a. His argumentation here, too, bears obvious marks of the dual nature of his thinking and Weltanschaunng; he cites proofs from the sciences to authenticate the stories of the Bible, such as the story of the flood, and he also utilizes some traditional arguments used already by Judah Halevi in Hakuzari such as the well-known proof of the revelation at Sinai. Contrary to the deists, this maskil accepts all the biblical miracles and prophecies, and endeavors to prove their authenticity. Schnaber accepts tradition, that is, Jewish tradition, without any question or doubt. 
prove that immortality of the soul had been alluded to in the Torah, contrary to the well-known argument that it had not and that it was introduced by Jesus, implying that Christianity has the sole divine truth. ${ }^{58}$ Schnaber seems to reject the deistic argument that, even if God had given the law to Israel, he has since disappeared from the scene. ${ }^{\mathbf{5 9}}$ Although Schnaber seems to accept the notion of the relativity of all traditions, another of the deistic beliefs, his acceptance clearly has a purpose: to show that various external traditions have indeed authenticated the Jewish tradition as written in the Torah. Now if even some non-Jews have accepted "the words of Moses, may he rest in peace, why is it that the children of Israel do not believe in the Torah of God," 60 he asks. His arguments are used against forces from within and without the Jewish spheres. All in all, writes Schnaber, "those who deny both the Torah and its fundamentals have not found any demonstrative proof to authenticate their words and to fight us." 61

It is no doubt the writing of a true believer, of a maskil who is versed in the European culture, yet is aware of the necessity of religion-to him the Jewish religion-for the preservation of social order, in effect for the preservation of the human race. ${ }^{62}$ The worship of God, the deeds (mitzvoth), are stressed as essential to religion. ${ }^{63} \mathrm{He}$ does accept also unconditionally the Oral Law. ${ }^{64}$

However, Schnaber adheres to the views expressed previously in his first book concerning the reasons why תורה שבעל פה had been given orally, and thus he reiterates the importance of

58 ibid., p. 6 ob.

59 ibid., p. 54 b.

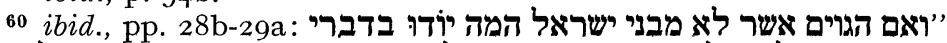

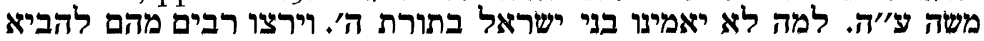

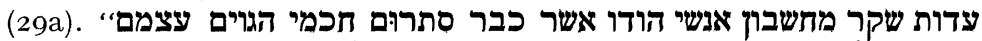

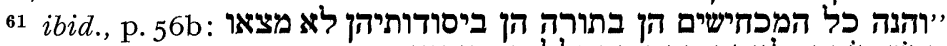
62 ibid., p. 5 ob.

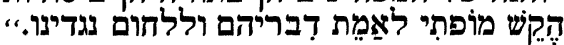

63 ibid., pp. 33b, 69b; see also pp. 5a-b.

64 ibid., pp. 56a, 6ra. 
this legal tool given to the rabbis of each generation. ${ }^{65}$ To this he adds another aspect of great significance: The reasons for the precepts [טעמי המצוות] are not included in the Oral Law (which has been put in writing since) for the same reason that the Oral Law itself was first given orally; namely, in order to allow for the subtleties of the oral interpretation as against the awkward, dependent, and inflexible nature of the written interpretation. " ${ }^{66}$ "And if the interpretation of the scriptures had been put in writing, there would not have been power [authority] in the hands of the sages to innovate a thing as per the necessity of time and place, for the masses would not accept from them any innovation except that which is written. For this reason it necessitated that the interpretation of the mitzvoth and their like, and the branching out of the dinim be given to the wise men in every generation orally." 67

Discussion of טעמי המצוות, it must be emphasized, played a vital role in the Haskalah writings in that it signified a step in the direction of religious reform. The reasons given for the precepts in that age of reason helped strengthen Judaism; however, they have been also instrumental in the deterioration of the religious observance. At times the rational explanation for the mitzvoth became the very reason for doing away with the observance of the mitzvoth, especially when the explanation emphasized some temporal aspect which somehow looked rather irrelevant in the then modern context. It is ironic that the talmudic apprehension concerning the reasons for the precepts has materialized. ${ }^{68}$

65 ibid., pp. 6rb-62a.

66 ibid., p. 6ra.

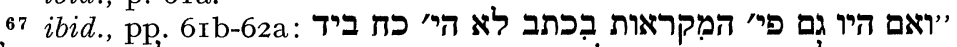

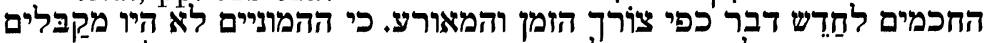

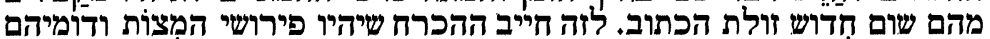

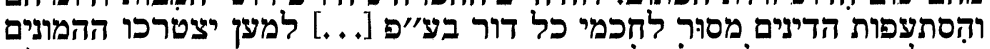

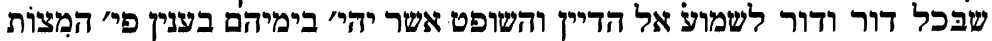
"וסעיפי הדינים פיזים (cf. note 26 above).

68 Sanhedvin, 2Ib: Rabbi Yitzhak suggests that giving reasons for precepts, or for injunctions, leads actually to transgression; he supports his view from Solomon who sinned in two injunctions re- 
Against this background, Schnaber's endeavors to authorize the rabbis of each generation to interpret the precepts are of utmost importance.

Another significant aspect of Schnaber's writing is the growing awareness of time in its relation to man and God. It appears that Schnaber feels that all matters involving man fall under the rule of time; time implies change, thus the principle of change in all human matters. Included in the latter are all religious matters which evolve around man. The only exclusion which does not fall under the rule of time is the existence of God. As such, it is the one and only fundamental of religion, according to Schnaber. A prophet may temporarily nullify the mitzvoth; indeed it is obligatory to follow that נביא אמת [true prophet], and the one who does not obey his instructions is rebelling against God. The only exception, according to the Hebrew maskil, is the above mentioned fundamental of religion, which is immutable. ${ }^{69} \mathrm{It}$ must be emphatically pointed out that Schnaber is very careful to establish the Maimonidian sources as an authority for his contentions. However, I believe this great awareness of the mutability of the mitzvoth and their dependence on the changing time is one of the best indicators of the age of secularism. To be more correct, it is an indicator of the period of transition from the holy to the profane.

In this volume, too, Schnaber cites Maimonides as the authoritative source on the necessity of certain temporary and timely changes in the written law. ${ }^{70}$ Like Moses Mendels-

garding a king, which had been given explanations in the Torah (cf. Deuteronomy I7:I6-I7; I Kings chs. Io, II; Yesodei Hatorah, p. 59b). Similarly we find in Midrash תמתומא Parashath 2, that the law-giver had not pronounced the reward and value of each and every mitzvah, for if he had revealed them, some of the mitzvoth would have prevailed and some others would have been abolished.

69 Shlosh 'Esveh Yesodei Hatorah, p. 2 b.

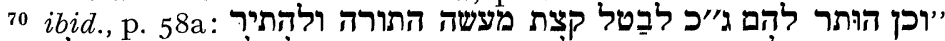

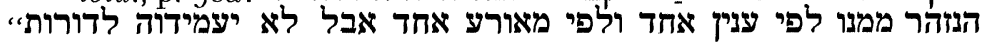
(citing Maimonides). 
sohn, he relies on Maimonides with regard to the probability of the issuance of a new Torah through a new revelation by God comparable to the one at Sinai. ${ }^{71}$ Similarly, through such a revelation God may remove the "stoney heart from within us," in which case the Torah as it is would not be needed, for people would achieve the goals of the Torah not through deeds, that is, not through the mitzvoth. ${ }^{72}$ As has been stressed before, although these enunciations are not entirely new in Jewish thought, against the background of the philosophy of Enlightenment, and in the context of Schnaber's other views, they do indeed represent the budding of religious reform thought. For it seems rather inconceivable that this maskil would come out straight forward with a declaration of reform; the legal groundwork has first to be prepared.

Schnaber's last book, published posthumously in I797, is entitled סלת מִנחה בלוּלה. The book contains short exegeses, interpretations and sermons on the Bible and on the Talmud. The author's explanation of the title, in the introduction, sets the tone of the whole book. "This offering," he writes, "is fine flour and clear of any foreign thoughts." 73 And surely it is styled after the old order in Judaism in form, language, and content. Many of his remarks regarding the limitation of philosophical investigation turns the wheels of Haskalah backwards to its early beginning. ${ }^{74}$ Utterances such as the one on the authorship of the book of Job are entirely of traditional Judaism. ${ }^{75}$ The only expression of Haskalah

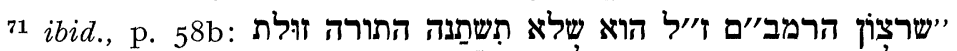

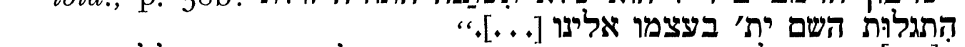

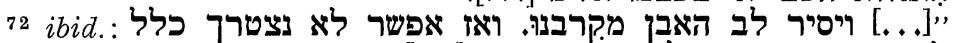

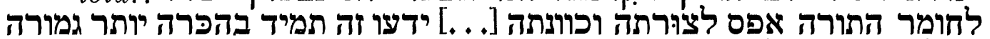

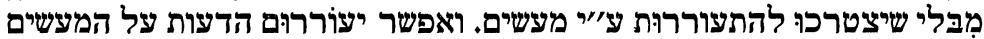

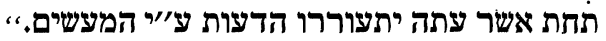

73 [An Offering of Mixed, Fine Flour] (Altona?,

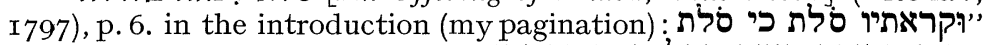

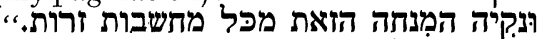

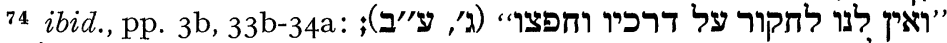

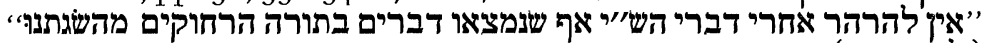

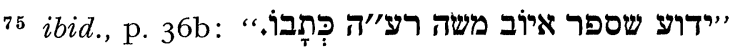

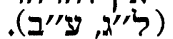


could be found in his citation from Maimonides of critical remarks on the Piyyutim, the liturgical poems, which have been the target of the maskilim, ${ }^{76}$ his scientific explanation of the biblical flood, ${ }^{77}$ and his moderate interpretation of the controversial saying "מנעו בניכם מן ההגיון" ["keep your children away from logic"].78 Likewise, his reference to

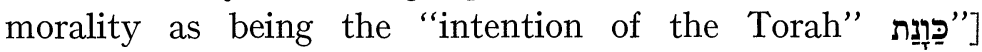

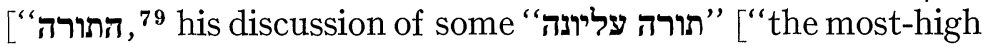
Torah"] which is not identical with the Torah and its mitzvoth, but is alluded to by them, ${ }^{80}$ and his stress on the necessity of "pure thought" combined with the good deed ${ }^{81}$ - they all are moderate, very moderate indeed, manifestations of this author's Enlightenment tendencies.

The author's introduction may give us the clue as to the conservative nature of the book. Schnaber considers the book as a thanks offering to God for saving him from death; ${ }^{82}$ the short pieces which he has been writing at random for years ${ }^{83}$ were selected because of their conservative, traditional

76 ibid., p. 66b. Cf. for example, Isaac Satanow's Mishlei Asaf [Proverbs of $A$ saf], I(Berlin, I789), pp. 94b, 24b-25a, 6b; vol. II (I792), p. $57 \mathrm{~b}$.

77 Soleth Minhah, pp. 23b-24a.

78 ibid., p. 48 a. Schnaber attempts to reconcile that talmudic maxim, which seems to contradict the fundamentals of the Enlightenment, with Haskalah. Accordingly, only children should not have access to [search, investigation] and מחשבה [thought, i.e., logic]; however, after they had mastered the Talmud they may engage in logic. Briefly, it should be pointed out that this saying appears very frequently in the Hebrew writings of the period. Rabbis who opposed the Haskalah and maskilim would utilize the saying in order to attack the enlighteners. The maskilim, on the other hand, endeavored to show that the rabbis twisted the original meaning of the Talmud and its interpreter (רשו"יו). Example of the use by the rabbis: Rabbi David Tevele's approbation to Wessely's (Warsaw, I9I4), p. 5; for the use by the maskilim, see for example קהלת מוּס (I750?), p. 3, and Divvei Shalom Ve'emeth, II, p. 2Ia.

79 Soleth Minhah, p. 57a.

80 ibid., p. 75 a.

81 ibid., p. I, in the introduction: "המתשבה הטהורה",

82 ibid., p. 3.

83 ibid., p. 5 . 
nature. To the student of Schnaber and of the Hebrew Haskalah in general, it comes as no surprise; this book, like many other works of the Hebrew maskilim, presents and represents the dual nature of the Hebrew Enlightenment in the beginning: progressive views tinted with traditional hues.

Schnaber's endeavors to introduce enlightenment into Judaism stem from his strong beliefs that there is no contradiction between the two; indeed, he felt that the former would and should enhance the latter. Even his demands for religious reforms are founded on traditional elements within the Halachah, and are given exclusively into the hands of the Jewish religious authorities, namely, the rabbis. It is a view of Judaism and an interpretation of it which differs from the one offered by the traditional rabbis, and as such it is innovative, and it contradicts the traditional, authoritative Judaism of the time. Yet it is possible that Schnaber was unaware of the explosive material that he was handling, and if he did, he felt very strongly that his was the only true interpretation of Judaism. 